\title{
Basal melt at NorthGRIP modeled from borehole, ice-core and radio-echo sounder observations
}

\author{
Dorthe DAHL-Jensen, ${ }^{1}$ Niels GUNDestruP, ${ }^{1}$ S. Prasad GOGineni, ${ }^{2}$ Heinz MilleR ${ }^{3}$ \\ ${ }^{1}$ Niels Bohr Institute of Astronomy, Physics and Geophysics, University of Copenhagen, Juliane Maries Vej 30, DK-2100 Copenhagen, Denmark \\ E-mail:ddj@gfy.ku.dk \\ ${ }^{2}$ Radar Systems and Remote Sensing Laboratory, University of Kansas, 2335 Irving Hill Road, Lawrence, KS 66045-7612, U.S.A. \\ ${ }^{3}$ Alfred Wegener Institute for Polar and Marine Research, Columbusstrasse, D-27568 Bremerhaven, Germany
}

\begin{abstract}
From temperature measurements down through the $3001 \mathrm{~m}$ deep borehole at the North Greenland Icecore Project (NorthGRIP) drill site, it is now clear that the ice at the base, $3080 \mathrm{~m}$ below the surface, is at the pressure-melting point. This is supported by the measurements on the ice core where the annual-layer thicknesses show there is bottom melting at the site and upstream from the borehole. Surface velocity measurements, internal radio-echo layers, borehole and ice-core data are used to constrain a timedependent flow model simulating flow along the north-northwest-trending ice-ridge flowline, leading to the NorthGRIP site. Also time-dependent melt rates along the flowline are calculated with a heat-flow model. The results show the geothermal heat flow varies from 50 to $200 \mathrm{~mW} \mathrm{~m}^{-2}$ along the $100 \mathrm{~km}$ section of the modeled flowline. The melt rate at the NorthGRIP site is $0.75 \mathrm{~cm} \mathrm{a}^{-1}$, but the deep ice in the NorthGRIP core originated $50 \mathrm{~km}$ upstream and has experienced melt rates as high as $1.1 \mathrm{~cm} \mathrm{a}^{-1}$.
\end{abstract}

\section{INTRODUGTION}

The North Greenland Icecore Project (NorthGRIP) deep drilling program is an international collaboration involving Denmark, Germany, Japan, Belgium, Sweden, Iceland, the U.S.A., France and Switzerland. The drill site is located at $75^{\circ} 10^{\prime} \mathrm{N}, 42^{\circ} 32^{\prime} \mathrm{W}$ in North Greenland at a surface elevation of $2921 \mathrm{~m}$ a.s.l. and an ice thickness of $3080 \mathrm{~m}$. The site is located $324 \mathrm{~km}$ downstream along the north-northwesttrending ice ridge from the top point of the Greenland ice sheet where the European drill site GRIP is located (DahlJensen and others, 1997, 2002; Johnsen and others, 1997). During the 2001 field season, a depth of $3001 \mathrm{~m}$ was reached and it became clear that the ice temperature was approaching the pressure-melting point and there would be basal melting at the bedrock (Dahl-Jensen and others, 1997; Grinsted and Dahl-Jensen, 2002). The temperature profile alone is not sufficient to determine the basal melt rate at the NorthGRIP site. Annual-layer thicknesses from the dated NorthGRIP ice core constrain the basal vertical velocity, thereby allowing a determination of the geothermal heat flow under the NorthGRIP area. After a presentation and discussion of the temperature profile, the ice-core data are used in a two-dimensional flowline model to determine the basal melt rate and geothermal heat flow along the northnorthwest-trending ice ridge leading to the NorthGRIP site.

\section{TEMPERATURES AT NORTHGRIP}

At the beginning of the 2001 field season, the temperatures are measured down through the $2930 \mathrm{~m}$ deep liquid-filled borehole with the University of Copenhagen (UCPH) borehole logger (Gundestrup and others, 1994). To minimize disturbances of the liquid temperature due to liquid exchange and drill heat, the borehole is left undisturbed for 9 months. The temperature measurements in the borehole liquid represent the ice temperatures within $0.05 \mathrm{~K}$ (Dahl-Jensen and others, 1998). The top $100 \mathrm{~m}$ of the borehole is not liquid-filled, and temperature measurements here are not used because air temperatures in this part of the borehole are disturbed by the pressure and temperature conditions in the subsurface drill trench.

The NorthGRIP and GRIP temperatures are presented in Figure 1. At NorthGRIP the surface temperature is $-31^{\circ} \mathrm{C}$, and the temperature at $2880 \mathrm{~m}$ depth is $-7.8^{\circ} \mathrm{C}$. The gradient of the temperature profile is $-2.8 \mathrm{~K}(100 \mathrm{~m})^{-1}$ at $2880 \mathrm{~m}$ depth. The dissipation energy between 2880 and $3080 \mathrm{~m}$ is negligible because the site is on an ice ridge with a surface velocity of only $1.33 \mathrm{ma}^{-1}$, so the temperature gradient is assumed unchanged here. The basal temperature is thus estimated to be $-2.4^{\circ} \mathrm{C}$. This is within the range of possible pressure-melting temperatures $\left(-2.0\right.$ to $\left.-2.8^{\circ} \mathrm{G}\right)$ of the basal ice under NorthGRIP (Paterson, 1994). The NorthGRIP temperature profile $\left(H=3080 \mathrm{~m}, a=0.195 \mathrm{ma}^{-1}\right.$, $T_{\text {sur }}=-31^{\circ} \mathrm{C}$ ) is compared to the GRIP temperature profile $\left(H=3023 \mathrm{~m}, \quad a=0.23 \mathrm{ma}^{-1}, T_{\text {sur }}=-31.7^{\circ} \mathrm{C}\right) \quad($ Clow and others, 1995; Gundestrup and Clow, 1997). For the upper $1000 \mathrm{~m}$, the ice-temperature undulations at the two sites are similar. The temperature undulations are remnants of surface temperatures in earlier warm and cold periods during the last 5000 years (the Little Ice Age (AD 14001900), the Medieval Warmth (AD 1000) and the Climatic Optimum (8-5 kyr BP); Dahl-Jensen and others, 1998). The basal temperature at GRIP is $-8.58^{\circ} \mathrm{C}$ and is below the pressure-melting point. The geothermal heat flow here has been modeled to be $Q_{\text {geo }}=51 \mathrm{~mW} \mathrm{~m}^{-2}$.

The temperature profile at NorthGRIP does not allow a determination of the geothermal heat flow, $Q_{\text {geo, }}$ because of 


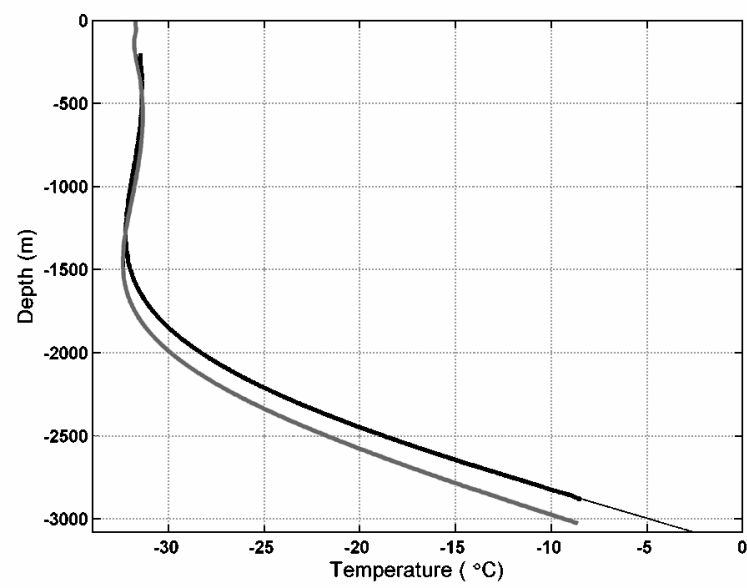

Fig. 1. The NorthGRIP and GRIP temperature profiles as functions of depth. At NorthGRIP the temperature profile (solid black line) was measured at the beginning of the 2001 field season to $2880 \mathrm{~m}$ depth. The ice is $3080 \mathrm{~m}$ deep, and an estimate of the temperatures in the last $200 \mathrm{~m}$ (thin black line) showes that the ice at the base is at the pressure-melting point $\left(-2.4^{\circ} \mathrm{C}\right)$. The GRIP temperature profile (solid gray line) was measured in 1995, 3 years after the drilling was successfully concluded. The temperatures in the upper $1000 \mathrm{~m}$ compare well, but the basal ice at GRIP is below the pressure-melting point of ice, whereas at NorthGRIP it is at pressure point.

melting of an unknown amount of basal ice. The heat flow through the ice is $Q_{\text {ice }}=-K \partial T / \partial z=55 \mathrm{~mW} \mathrm{~m}^{-2}$. The heat used to melt ice is the difference between the incoming heat, $Q_{\text {geo, }}$ and the outgoing heat, $Q_{\text {ice }}$, at the base

$$
Q_{\text {melt }}=Q_{\text {geo }}-Q_{\text {ice }} \text {. }
$$

A one-dimensional time-dependent energy-balance equation (Johnsen and others, 1995; Dahl-Jensen and others, 1998) is used to model the temperature distribution through the ice as a function of the climate conditions on the surface and the geothermal heat flow from the bedrock:

$$
\rho c \frac{\partial T}{\partial t}=K \frac{\partial^{2} T}{\partial z^{2}}-\rho c w \frac{\partial T}{\partial z},
$$

where $T(z, t)$ is the temperature as a function of $z$, the vertical coordinate, and $t$, the time. $\rho$ is the density of ice, $c(T)$, the specific heat capacity of ice, and $K(T)$ the conductivity of ice. The vertical velocity, $w(z, t)$, in the ice is given by the Dansgaard-Johnsen equations (Dansgaard and Johnsen, 1969; Johnsen and others, 1995):

$$
w=\left\{\begin{array}{cc}
w_{\text {base }}-r r\left[F_{\mathrm{B}} z+\frac{1}{2}(1-F B) \frac{z^{2}}{h}\right] & z \in[0, h[ \\
w_{\text {base }}-r r\left[z-\frac{1}{2} h(1-F B)\right] & z \in[h, H],
\end{array}\right.
$$

where $z=0$ is the ice-bedrock interface and $z=H$ is the ice surface, $w_{\text {base }}$ is the (negative) melt rate, $F_{\mathrm{B}}$ is the fraction of the horizontal surface velocity that is assumed to be the basal sliding velocity, $h$ is the distance above bedrock of the kink in the Dansgaard-Johnsen model, $H$ is the ice equivalent ice thickness and $r r$ is defined as

$$
r r=\frac{a+w_{\text {melt }}}{H-\frac{1}{2} h\left(1-F_{\mathrm{B}}\right)},
$$

where $a(t)$ is the accumulation rate. The energy-balance
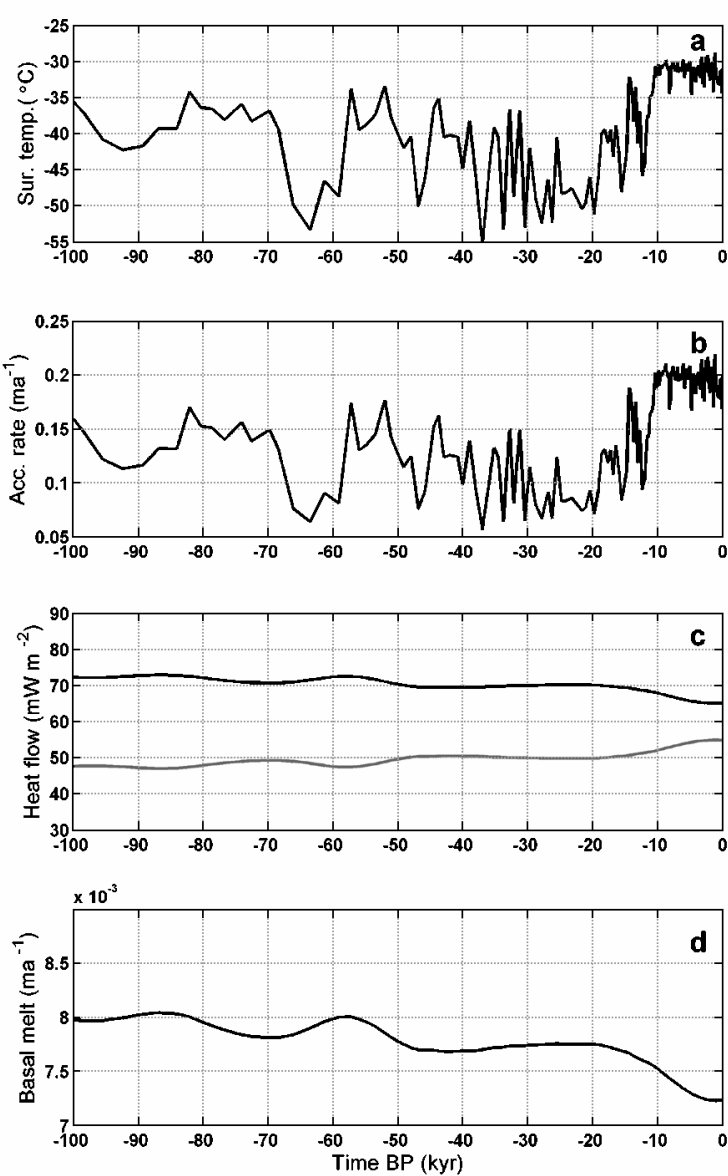

Fig. 2. A one-dimensional heat-flow model is used to model the observed temperature through the ice at NorthGRIP. The $100 \mathrm{kyr}$ long climate history used as surface boundary to the heat-flow Equation (2) consists of the surface temperature history from GRIP (Dahl-Fensen and others, 1998) (a) and the accumulation rate from NorthGRIP (Fohnsen and others, 2001) (b). (c) When the geothermal heat flow is set to $120 \mathrm{~mW} \mathrm{~m}^{-2}, 45-55 \mathrm{~mW} \mathrm{~m}^{-2}$ is conducted though the ice at the base (gray line) while $65-75 \mathrm{~mW} \mathrm{~m}^{-2}$ is used to melt ice at the bedrock (black line). The corresponding basal melt rate is shown in $(d)$.

equation (2) is solved for the last $100 \mathrm{kyr}$ with the boundary conditions:

$$
\begin{aligned}
T(H, t) & =T_{\text {climate }}(t) \\
a(t) & =a_{\text {climate }}(t) \\
-K_{\text {rock }}\left(\frac{\partial T}{\partial z}\right)_{z=0(\text { rock })} & =-K_{\text {ice }}\left(\frac{\partial T}{\partial z}\right)_{z=0(\text { ice })}+\rho L \mid w_{\text {base }}, \\
Q_{\text {geo }} & =-K_{\text {rock }}\left(\frac{\partial T}{\partial z}\right)_{z=-3000 \mathrm{~m}} .
\end{aligned}
$$

The first two equations describe the surface boundary conditions, the climate parameters. The time-dependent surface temperatures and accumulation rates (Fig. 2a and b) are determined for the last $100 \mathrm{kyr}$ by relating their values to the dated stable-oxygen-isotope values in the NorthGRIP ice cores (Johnsen and Dansgaard, 1992; Dahl-Jensen and others, 1993; Johnsen and others, 1995, 1999, 2001). The third equation accounts for heat-flow balance at the boundary between ice and rock, $z=0 . L$ is the specific latent heat of fusion for ice. The last equation is the boundary for the geothermal heat flow placed $3000 \mathrm{~m}$ down in the bedrock, i.e. at $z=-3000 \mathrm{~m}$. 

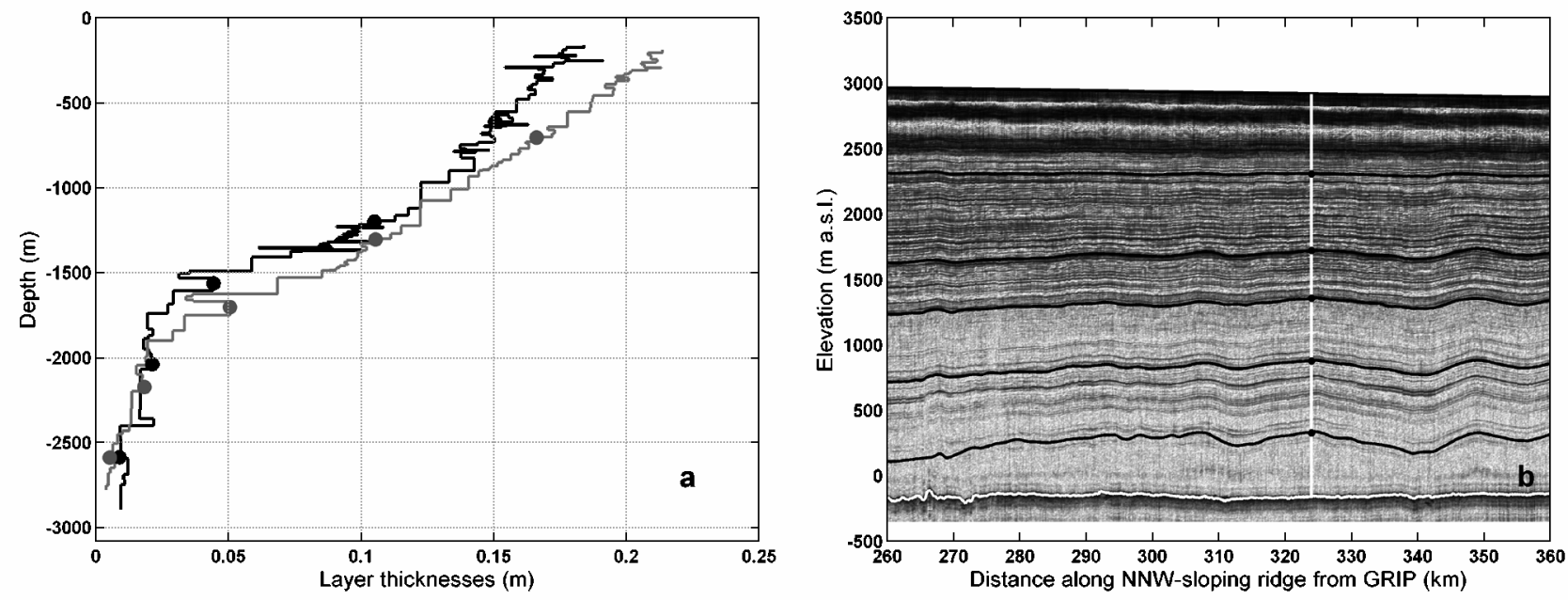

Fig. 3. The layer thickness down through the ice at NorthGRIP (black line) and GRIP (grayline) are presented in ( a). The layer thickness profiles are produced from 130 dated reference horizons from the two deep ice cores. In order to model the melt rate at NorthGRIP, a $100 \mathrm{~km}$ section of an airborne RES profile from 1999 along the north-northwest-trending ice ridge leading to the NorthGRIP site is used (b) (Chuah and others, 1996; Gogineni and others 1998, 2001; Kanagaratnam and others, 2001). The internal reflectors are related to the dated NorthGRIP ice core, and five layers are selected and used to constrain the basal melt rate using a two-dimensional model, the dated ice core and the RES profile. The NorthGRIP site is marked with a vertical white line at $x=324 \mathrm{~km}$. The five selected internal reflectors are shown with black curves, and their intersections with the NorthGRIP borehole are marked with black dots in ( $b$ ). On the layer-thickness profiles $(a)$, the depth of the selected reflectors is marked with gray dots on the GRIP layer-thickness profile and with black dots on the NorthGRIP profile.

To investigate for possible values of the unknown geothermal heat flow, the energy-balance equation is solved for different values. The results from the calculations at NorthGRIP determine that when the heat flow is $<45 \mathrm{~mW}$ $\mathrm{m}^{-2}$ the basal temperatures have been below the melting point $\left(-2.4^{\circ} \mathrm{C}\right)$ for the last $100 \mathrm{kyr}$ and no basal melting has taken place. When the geothermal heat flow is increased to $55 \mathrm{~mW} \mathrm{~m}^{-2}$, the basal temperature has been at the pressuremelting point for the whole $100 \mathrm{kyr}$ period. Further increasing the heat flow increases the melt rate by $1 \mathrm{~mm} \mathrm{a}^{-1}$ for each additional $9.7 \mathrm{~mW} \mathrm{~m}^{-2}$. When the geothermal heat flow is $>55 \mathrm{~mW} \mathrm{~m}^{-2}$, the time-dependent temperatures in the ice are not sensitive to the value of $Q_{\text {geo }}$. The basal temperatures are always at the melting point, and the heat flow through the ice, $Q_{\text {ice, }}$ is determined by the temperature gradient at the base. This temperature gradient changes slightly with time as ice temperatures react to time-dependent surface temperatures and accumulation rates. An example of the model results is presented in Figure 2c for the geothermal heat-flow value $Q_{\text {geo }}=120 \mathrm{~mW} \mathrm{~m}^{-2}$, which is believed to be the most likely value at NorthGRIP (see further below). The basal ice is at the pressure-melting point through the whole period, and $Q_{\text {ice }}$ varies from 45 to $55 \mathrm{~mW} \mathrm{~m}^{-2}$. At the present time, $t=0$ years, the cold temperature wave from the glacial time has reached the bedrock at NorthGRIP, and the temperature gradient therefore has its maximum value for the $100 \mathrm{kyr}$ period. A maximum amount of heat flow, $Q_{\text {ice }}=55 \mathrm{~mW} \mathrm{~m}^{-2}$, passes into the ice for $t=0$ years. The heat available for melting $Q_{\text {melt }}=Q_{\text {geo }}-Q_{\text {ice }}$ is also shown in Figure 2c, and the melt rates are shown in Figure 2d. The melt rate varies between 0.72 and $0.80 \mathrm{~cm} \mathrm{a}^{-1}$ during the $100 \mathrm{kyr}$ period, with maximum values at $60-100 \mathrm{kyr}$ BP. The present values are the lowest during the $100 \mathrm{kyr}$ period. The above calculations show that when the basal ice is at the pressure-melting point, the geothermal heat flow can be determined if the basal melt rate is known.

\section{BASAL MELT RATES AND GEOTHERMAL HEAT FLOW AT NORTHGRIP}

\section{The ice-core data}

The NorthGRIP ice core can be dated by matching dated reference horizons between the GRIP ice core and the NorthGRIP ice core. One hundred and thirty reference horizons are identified from the volcanic markers and the sharp climatic transitions found in the stable-oxygen-isotope profiles. Figure $3 \mathrm{a}$ presents the annual-layer thicknesses down through the GRIP and NorthGRIP ice cores based on the 130 dated reference horizons. Near the surface, the layer thickness is $0.195 \mathrm{~m}$ at NorthGRIP and $0.23 \mathrm{~m}$ at GRIP; both values correspond to the present accumulation rates at the sites. The layer thicknesses at NorthGRIP are thinner than those at GRIP in the region from the surface to $2000 \mathrm{~m}$ depth. Below this depth, the NorthGRIP annual layers are thicker. At the NorthGRIP depth of 2895 m, where the ice is $104 \mathrm{kyr}$ old, layer thicknesses at NorthGRIP are still of the order of $1 \mathrm{~cm}$. At GRIP the $104 \mathrm{kyr}$ old ice is found at $2750 \mathrm{~m}$ depth, and the layer thickness here is estimated to be $0.5 \mathrm{~cm}$. The $104 \mathrm{kyr}$ old layers have double the thickness at NorthGRIP that they have at GRIP, and the NorthGRIP layers do not seem to be thinning to zero at the bedrock

\section{A one-dimensional flow model approach}

A simple fit to the NorthGRIP annual layers presented in Figure $3 \mathrm{a}$ is attempted with a one-dimensional flow model given in Equations (3) and (4) and the climate-dependent surface accumulation rate from Figure 2b. The ice thickness is assumed to be constant with time. A best fit to the annual layers is made with $h=1400 \mathrm{~m}, F_{\mathrm{B}}=0.135$ and a mean basal melt rate given by $v_{\text {base }}=-0.77 \mathrm{~cm} \mathrm{a}^{-1}$ (Grinsted and DahlJensen, 2002). This corresponds to a geothermal heat flow of $120 \mathrm{~mW} \mathrm{~m}^{-2}$, the value used for the results presented in Figure 2c and $\mathrm{d}$. 


\section{A two-dimensional flow model approach}

A better reconstruction of the basal melt rates requires a timedependent two-dimensional flow model because the ice found in the NorthGRIP core originates from the surface upstream from the drill site along the north-northwest-trending ice ridge. The surface velocity at NorthGRIP is $1.33 \mathrm{~m} \mathrm{a}^{-1}$ (Hvidberg and others, 2002). Thus the $100 \mathrm{kyr}$ old ice found at $2850 \mathrm{~m}$ depth originates from the surface in the area $50 \mathrm{~km}$ upstream. The estimated melt rate from the layer thickness at NorthGRIP must be an average from the $50 \mathrm{~km}$ region from which the ice has flowed during the last $100 \mathrm{kyr}$. An airborne radio-echo sounder (RES) profile from GRIP to NorthGRIP along the north-northwest-trending ice ridge was obtained in 1999 with an ice-penetrating radar on a NASA P3 aircraft (Chuah and others, 1996; Dahl-Jensen and others, 1997; Gogineni and others, 1998, 2001; Fahnestock and others, 2001; Kanagaratnam and others, 2001). The $100 \mathrm{~km}$ section of the RES profile covering the flow region leading to the NorthGRIP ice core is shown in Figure 3b. The vertical resolution of the image is about $4.6 \mathrm{~m}$ and the horizontal resolution is $160 \mathrm{~m}$. Internal layers are traceable at $700-2500 \mathrm{~m}$ depth. The reflectors above $700 \mathrm{~m}$ are blocked in online data processing to obtain maximum resolution of the deeper reflectors. Below $2500 \mathrm{~m}$, the reflectors (if any) are too weak to be detected. The internal reflectors are layers of the same age, isochrones (Gudmandsen, 1975; Hammer, 1980). In the upper part of the ice, the reflectors are believed to coincide with volcanic horizons and density changes (Fujita and others, 1999; Hempel and others, 2000; Kanagaratnam and others, 2001), while deeper down they probably coincide with the abrupt climate transitions. A prominent feature is the change between closely spaced reflectors and no reflectors found at $1600 \mathrm{~m}$ depth at NorthGRIP. This boundary marks the transition from the cold Glacial period to the warm Bølling-Allerød period (14 kyr BP) and can be traced on most of the RES profiles obtained from the Greenland ice sheet (Gudmandsen, 1975). The age of the internal reflectors can be found by comparing the RES data with the ice-core data at NorthGRIP. The five most clearly traced reflectors are marked on the RES profile (Fig. $3 \mathrm{~b}$ ). The age of the reflectors ranges from 3.4 to $77.2 \mathrm{kyr}$ BP. The internal layers have undulations with amplitudes of up to $200 \mathrm{~m}$ that can be explained neither by flow over a rough bedrock nor by surface accumulation variations. The internal layers are undulating upwards at the NorthGRIP site.

With the knowledge from the NorthGRIP ice core that there is basal melt at NorthGRIP, it is concluded that there must be basal melt along the whole section of the ice-ridge flowline presented in Figure $3 \mathrm{~b}$. The dipping of the isochrones therefore cannot be explained by shifting melting and non-melting regions along the line. The undulations must be caused by variations of the melt rate and thus the geothermal heat flow along the line or by variations in extending flow perpendicular to the ridge. A close net of airborne RES profiles in the NorthGRIP region was made in 1996 and 1997 by the Alfred Wegener Institute research group (Göktas, 1999). The recorded internal layers and bedrock reflectors do not support the idea of rapid changes in the flow conditions perpendicular to the ice-ridge flowline. We will assume the undulations of the internal layers are caused by variations of the geothermal heat flow along the flowline. A simple time-dependent two-dimensional flow model is used to model the flow of the isochrones with time. Equations
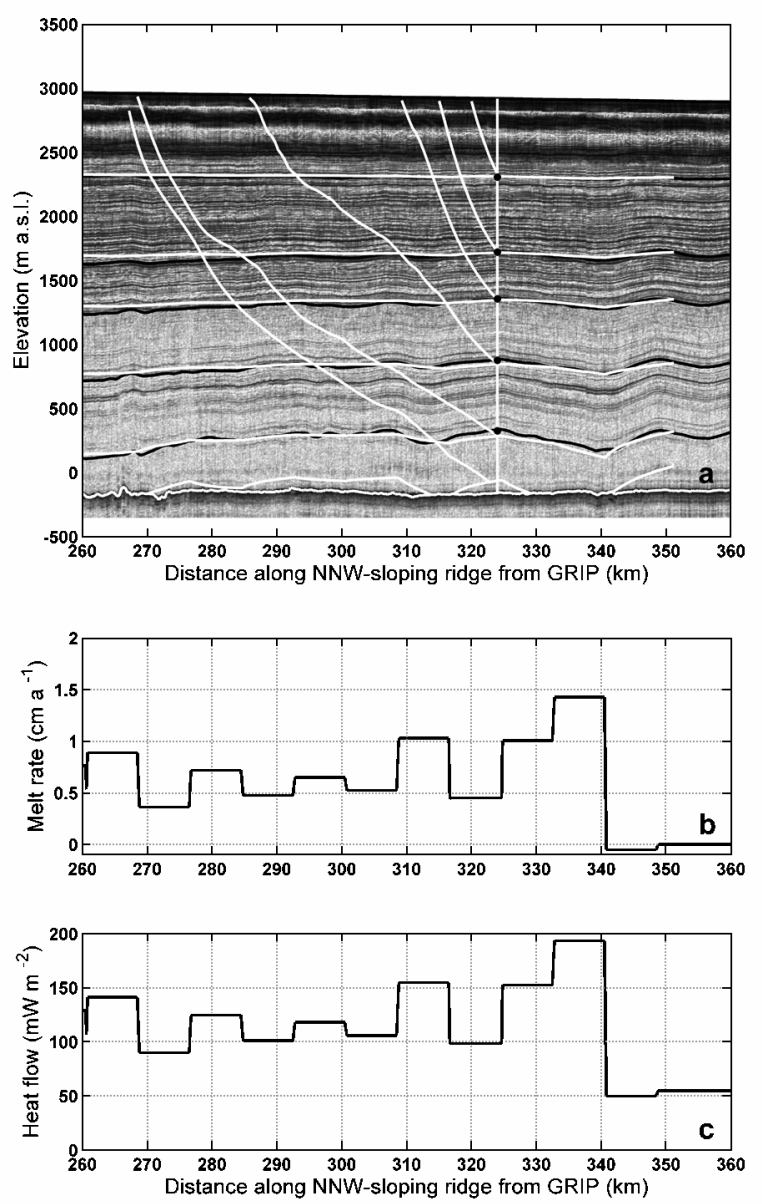

Fig. 4. (a) The five isochrones (white curves) modeled using the melt rates presented in $(b)$ are compared with the observed internal reflectors (black curves). The modeled isochrones are capable of catching the undulations of the internal layers. Flow paths for ice found at the NorthGRIP drill site are shown as solid white curves. The five upper flow paths correspond to the five selected depths shown in Figure 3, while the deepest flow path models the flow of ice that originated on the surface $50 \mathrm{~km}$ upstream at $100 \mathrm{kyr}$ BP. This ice is found at 2850 m depth in the NorthGRIP ice core. (b) The basal melt rates along the flowline. The melt rates are seen to vary along the flowline, with minimum values at the NorthGRIP site.

(c) The corresponding geothermal heat flow.

$(2-5)$ are used together with the corresponding equation for the horizontal velocity:

$$
u=\left\{\begin{array}{cc}
u_{\mathrm{sur}}\left[\left(1-F_{\mathrm{B}}\right) \frac{z}{h}+F_{\mathrm{B}}\right) & z \in[0, h[, \\
u_{\text {sur }} & z \in[h, H]
\end{array}\right.
$$

where $u_{\text {sur }}$ is the surface velocity determined by:

$$
\begin{aligned}
u_{\text {sur }}(x, t)= & u_{\text {sur }}\left(x_{\text {NorthGRIP }}, t\right) \\
& {\left[\frac{H(x)}{H\left(x_{\text {NorthGRIP }}\right)}\right]^{4}\left[\frac{\frac{\partial S(x)}{\partial x}}{\left.\frac{\partial S\left(x_{\text {NorthGRIP }}\right)}{\partial x}\right]^{3},},\right.}
\end{aligned}
$$

where $S(x)$ is the surface elevation and $H(x)$ is the ice thickness. NorthGRIP is placed at $x_{\text {NorthGRIP }}=324 \mathrm{~km}$ along the north-northwest-trending ice-ridge flowline beginning at the summit of the Greenland ice sheet. The present surface velocity at NorthGRIP, $u_{\text {sur }}\left(x_{\text {NorthGRIP }}, 0\right)=1.33 \mathrm{~m} \mathrm{a}^{-1}$ (Hvidberg and others, 2002), and the present velocities modeled by Equation (7) are in agreement with the velocities 
determined from the NorthGRIP strain net (Hvidberg and others, 2002). The time dependence of the horizontal velocity is assumed to be

$$
u_{\text {sur }}(x, t)=\frac{a_{\text {NorthGRIP }}(t)}{a_{\text {NorthGRIP }}(0)} u_{\text {sur }}(x, 0) .
$$

The ice thickness, $H(x)$, has been determined from the surface and bedrock reflectors traced on the RES profile, and the surface gradients $\partial S / \partial x$ are determined from the surface elevations (Ekholm and others, 1995; Ekholm, 1996). The ice thickness is assumed to be constant with time. The five traced isochrones with ages 3.4, 7.9, 14.0, 37.2 and 77.2 kyr BP are used to constrain the basal melt rates. A first model run is made assuming there is no basal melt during the 100 kyr modeled. The modeled no-melt isochrones are found at higher elevations than the corresponding observed isochrones. This is expected because the observed isochrones are dragged down by basal melt. The unknown melt rates along the flowline are estimated as average values for each $8 \mathrm{~km}$ section along the flowline. Perturbations from the non-melt isochrones are modeled for each $8 \mathrm{~km}$ section of the flowline by assuming a melt rate of $1 \mathrm{~cm} \mathrm{a}^{-1}$ in the sections one by one. A least-squares fit of the perturbed isochrones to the observed isochrones determines the best values of the melt rates for each of the $8 \mathrm{~km}$ sections along the flowline. The melt rates thereby calculated are presented in Figure 4b. It is seen that the melt rate varies between 0.4 and $1.1 \mathrm{~cm} \mathrm{a}^{-1}$ along the $50 \mathrm{~km}$ section of the flowline leading to the NorthGRIP borehole. The average value of the melt rate is $0.7 \mathrm{~cm} \mathrm{a}^{-1}$, in agreement with the one-dimensional estimate. Using the estimated melt rate along the flowline produces the modeled isochrones, which are shown as solid white lines in Figure $4 \mathrm{a}$. The flow of the ice leading to the depth of the five selected reflectors and of the $100 \mathrm{kyr}$ old ice found at $2850 \mathrm{~m}$ depth in the NorthGRIP borehole is included in Figure 4a.

\section{DISGUSSION AND GONCLUSIONS}

The temperature calculations show that the geothermal heat flow in the vicinity of NorthGRIP must be $>55 \mathrm{~mW} \mathrm{~m}^{-2}$ in order to match the observed temperature profile in the borehole. The basal ice is at the pressure-melting point, and the amount of melt cannot be constrained by the energy-balance equation alone. When the heat-flow model is combined with information on annual-layer thickness from the NorthGRIP ice core, the melt rate can be constrained to be $0.75 \mathrm{~cm} \mathrm{a}^{-1}$. The heat-flow calculations show a decrease of $0.1 \mathrm{cma}^{-1}$ during the last $100 \mathrm{kyr}$ because of ice-temperature changes with varying climate. The estimated heat flow can be translated to a geothermal heat flow of $120 \mathrm{~mW} \mathrm{~m}^{-2}$.

The airborne RES profile along the north-northwesttrending ice-ridge flowline leading to the NorthGRIP drill site reveals very detailed internal reflectors that are undulating. The internal layers are modeled by assuming that the cause of the undulations is variations in geothermal heat flow and thereby melt rates along the flowline. The $100 \mathrm{kyr}$ old ice that is found at $2850 \mathrm{~m}$ depth in the NorthGRIP ice core originates $50 \mathrm{~km}$ upstream of the drill site. The ice found in the NorthGRIP ice core has moved over regions where the melt rate has changed from 0.4 to $1.1 \mathrm{~cm} \mathrm{a}^{-1}$. This corresponds to geothermal heat-flow levels of $90-160 \mathrm{~mW}$ $\mathrm{m}^{-2}$. The melt-rate values estimated from the two-dimen- sional modeling have average values that match the onedimensional modeling values.

The geothermal heat flow is very high along the whole region of the investigated flowline, and the variations in geothermal heat-flow values suggest some very prominent geological structures under the ice. The investigation of Fahnestock and others (2001) over the onset area of the northwest ice stream originating $170 \mathrm{~km}$ south of NorthGRIP close to the ice ridge reveals even higher melt rates and geothermal heat flow. Very little is known about the geological structure of the bedrock under the Greenland ice sheet. Observations of heat flow from borehole measurements in north Canada show that the heat flow can vary over small distances (Majorowicz and Embry, 1998). The internal layers from the airborne RES profiles together with ice-core data from the NorthGRIP site are used to calibrate the models. This approach offers an opportunity to map the unknown geothermal properties of the bedrock under the Greenland ice sheet with a very high resolution.

\section{ACKNOWLEDGEMENTS}

The NorthGRIP Project is directed and organized by the Department of Geophysics at the Niels Bohr Institute, University of Copenhagen. It is supported by funding agencies in Denmark, Belgium, France, Germany, Iceland, Japan, Sweden, Switzerland and the U.S.A. Radar profiles are collected as a part of the NASA Program for Arctic Regional Climate Assessment.

\section{REFERENCES}

Chuah, T. S., S. P. Gogineni, C. Allen and B. Wohletz. 1996. Radar thickness measurements over the northern part of the Greenland ice sheet. Lawrence, KS, University of Kansas Center for Research Inc. Radar Systems and Remote Sensing Laboratory. (Technical Report 10470-3.)

Clow, G. D., E. D. Waddington and N. Gundestrup. 1995. High-precision temperature measurements in the GISP2 and GRIP boreholes. Arct. Res. U.S., 9, Fall/Winter, 44-47.

Dahl-Jensen, D., S. J. Johnsen, C. U. Hammer, H. B. Clausen and J. Jouzel. 1993. Past accumulation rates derived from observed annual layers in the GRIP ice core from Summit, central Greenland. In Peltier, W. R., ed. Ice in the climate system. Berlin, etc., Springer-Verlag, 517-532. (NATO ASI Series I: Global Environmental Change 12.)

Dahl-Jensen, D. and 9 others. 1997. A search in north Greenland for a new icecore drill site. F. Glaciol., 43(144), 300-306.

Dahl-Jensen, D. and 6 others. 1998. Past temperatures directly from the Greenland ice sheet. Science, 282(5387), 268-271.

Dahl-Jensen, D. and 8 others. 2002. The NorthGRIP deep drilling programme. Ann. Glaciol., 35, 1-4.

Dansgaard,W. and S. J. Johnsen. 1969. A flow model and a time scale for the ice core from Camp Century, Greenland. F. Glaciol., 8(53), 215-223.

Ekholm, S. 1996. A full coverage, high resolution topographic model of Greenland computed from a variety of digital elevation data. 7. Geophys. Res., 101(B10), 21,961-21,972.

Ekholm, S., R. Forsberg and J.M. Brozena. 1995. Accuracy of satellite altimeter elevations over the Greenland ice sheet. f. Geophys. Res., $\mathbf{1 0 0}(\mathrm{C} 2)$, 2687-2696.

Fahnestock, M., W. Abdalati, I. Joughin, J. Brozena and P. Gogineni. 2001. High geothermal heat flow, basal melt, and the origin of rapid ice flow in central Greenland. Science, 294(5550), 2338-2342.

Fujita, S. and 6 others. 1999. Nature of radio-echo layering in the Antarctic ice sheet detected by a two-frequency experiment. 7. Geophys. Res., 104(B6), $13,013-13,024$.

Gogineni, S., T. Chuah, C. Allen, K. Jezek and R. K. Moore. 1998. An improved coherent radar depth sounder. f. Glaciol., 44(148), 659-669.

Gogineni, S. and 9 others. 2001. Coherent radar ice thickness measurements over the Greenland ice sheet. F. Geophys. Res., 106(D24), 33,761-33,772.

Göktas, F. 1999. Ergebnisse der Untersuchung des grönländischen Inlandeises mit dem elektromagnetischen Reflexionsverfahren in der Umgebung von GGRIP. Ber. Polarforsch./Rep. Pol. Res. 336. 
Grinsted, A. and D. Dahl-Jensen. 2002. A Monte Carlo-tuned model of the flow in the NorthGRIP area. Ann. Glaciol., 35, 527-530.

Gudmandsen, P. 1975. Layer echoes in polar ice sheets. F. Glaciol., 15(73), 95-101. Gundestrup, N. S. and G. D. Clow. 1997. Logging of the GRIP and GISP2 boreholes. [Abstract.] Eos, 78(46), Fall Meeting Supplement, F7.

Gundestrup, N. S., H. B. Clausen and B. L. Hansen. 1994. The UCPH borehole logger. Natl. Inst. Polar Res. Mem., Special Issue 49, 224-233.

Hammer, C. U. 1980. Acidity of polar ice cores in relation to absolute dating, past volcanism, and radio-echoes. F. Glaciol., 25(93), 359-372.

Hempel, L., F. Thyssen, N. Gundestrup, H. B. Clausen and H. Miller. 2000. A comparison of radio-echo sounding data and electrical conductivity of the GRIP ice core. F. Glaciol., 46(154), 369-374.

Hvidberg, C. S., K. Keller and N. S. Gundestrup. 2002. Mass balance and ice flow along the north-northwest ridge of the Greenland ice sheet at NorthGRIP. Ann. Glaciol., 35, 521-526.

Johnsen, S. J. and W. Dansgaard. 1992. On flow model dating of stable isotope records from Greenland ice cores. In Bard, E. and W. S. Broecker, eds. The last deglaciation: absolute and radiocarbon chronologies. Berlin, etc., SpringerVerlag, 13-24. (NATO ASI Series I: Global Environmental Change 2.)

Johnsen, S., D. Dahl-Jensen, W. Dansgaard and N. Gundestrup. 1995.
Greenland palaeotemperatures derived from GRIP bore hole temperature and ice core isotope profiles. Tellus, 47B, 624-629.

Johnsen, S. J. and 14 others. 1997. The $\delta^{18} \mathrm{O}$ record along the Greenland Ice Core Project deep ice core and the problem of possible Eemian climatic instability. F. Geophys. Res., 102(C12), 26,397-26,410.

Johnsen, S. J., H. B. Clausen, J. Jouzel, J. Schwander, A. E. Sveinbjörnsdóttir and J. White. 1999. Stable isotope records from Greenland deep ice cores. In Wettlaufer, J. S., J. G. Dash and N. Untersteiner, eds. Ice physics and the natural environment. Berlin, etc., Springer-Verlag, 89-107. (NATO ASI Series I: Global Environmental Change 56.)

Johnsen, S. J. and8 others. 2001. Oxygen isotope and palaeo-temperature records from six Greenland ice-core stations: Camp Century, Dye-3, GRIP, GISP2, Renland and NorthGRIP. 7. Quat. Sci., 16(4), 299-307.

Kanagaratnam, P., S. P. Gogineni, N. Gundestrup and L. Larsen. 2001. High-resolution radar mapping of internal layers at the North Greenland Ice Core Project. 7. Geophys. Res., 106(D24), 33,799-33,811.

Majorowicz, J. A. and A. F. Embry. 1998. Present heat flow and paleogeothermal regime in the Canadian Arctic margin: analysis of industrial thermal data and coalification gradients. Tectonophysics, 291, 141-159.

Paterson, W. S. B. 1994. The physics of glaciers. Third edition. Oxford, etc., Elsevier 